\title{
RELIGIOUS AWARENESS AND RITUAL PRACTICES IN THE TAREKAT QADIRIYAH WA NAQSYABANDIYAH SURYALAYA
}

\author{
Jamaludin \\ Institut Agama Islam Latifah Mubarokiyah Tasikmalaya, \\ Indonesia \\ E-mail: doktor_jamaludin@yahoo.com \\ Solihah Sari Rahayu \\ Institut Agama Islam Latifah Mubarokiyah Tasikmalaya, \\ Indonesia \\ E-mail: solihah.sr2@gmail.com \\ Muhamad Dani Somantri \\ Institut Agama Islam Latifah Mubarokiyah Tasikmalaya, \\ Indonesia \\ E-mail: muhamaddanisomantri34@gmail.com
}

\begin{abstract}
This article seeks to reveal the religious experiences of the members of the Tarekat Qadiriyah wa Naqsyabandiyah (TQN) in Suryalaya, Tasikmalaya, West Java. Using a phenomenological approach, this article finds that TQN followers exhibit religious awareness and obedience to legal norms, reflected in various ritual practices, such as dhikr (remembrance), khataman (completing the reading of the Qur'ān), manakiban (reciting the saint's hagiography), riyadab (spiritual exercises), tawassul (mediating), and bajj (pilgrimage). The religious awareness is built upon the belief in achieving good morality as the attribute of a perfect man (insan kamil). The sociostructural diversity of the TQN community in social life is manifested in complexity of hierarchies involved in the tarekat system: murshid (spiritual leader); representatives of talgin which include intellectuals/modernist, ulama/ traditionalist, scholar/neo-traditionalist; preachers from the realms of pesantren, university, and politics. This article argues that the relationship between different hierarchies of membership in the TQN with regard to
\end{abstract}


religious awareness is based on the understanding toward the tarekat teaching provided by the spiritual leader.

Keywords: Nation; diversity; social life; TQN.

\section{Introduction}

The crisis that hit Indonesian increasingly penetrated various aspects of the nation's life. It began with a crisis of faith which then led to a crisis of morality, followed by economic, political, social and cultural crisis. ${ }^{1}$ The crisis manifests in various riots, violations of human rights, ${ }^{2}$ social inequality, domestic violence, ${ }^{3}$ crimes, ${ }^{4}$ sexual harassment, ${ }^{5}$ juvenile delinquency, ${ }^{6}$ etc. All these are assumed to have been causes of the decrease in the appreciation toward people's religiosity of the It is admitted that Indonesian is a nation with high awareness of diversity, as reflected in the slogan "diversity in unity" (Bhinneka Tunggal Ika), and the two principles in Pancasila (the Oneness of God and Indonesian Unity being central in relation to other principles. However, one of the significant problems is concerned with people's religiosity, which tends to be formalistic or legalistic (figh-oriented), while neglecting the essential meaning of religious teaching. Consequently, this tendency leads to a rigid and formalistic religiosity, rather than to a more substantive and spiritual one. ${ }^{7}$ As a matter of fact, legalistic orientation tends to be dominant over spirituality of human life.

This social reality results in textual-juristic understanding of religion, lack of ethical nuances, and therefore leads to decadence

\footnotetext{
${ }^{1}$ Simuh, Tasawuf dan Krisis (Yogyakarta: Pustaka Pelajar, 2001), 12.

2 "Kasus-Pelanggaran-Hak-Asasi-Manusia," available at http://www.yoedha. com/2012/01/kasus-pelanggaran-hak-asasi-manusia.html. accessed on March $17,2018$.

3 "Memprihatinkan-Jumlah-Kasus-Kdrt-Meningkat," available at http://jurnal berita.com/2012/05/memprihatinkan-jumlah-kasus-kdrt-meningkat. accessed on March 17, 2018.

4 "Berita-Berita-Kriminalitas-Terbaru," available at http://beritaterpopuler. com/berita/berita-kriminalitas-terbaru.html. accessed on March 17, 2018.

5 "Pelecehan Seksual," available at http://www.merdeka.com $/ \mathrm{tag} / \mathrm{p} / \mathrm{matcont}-$ pelecehan-seksual/ accessed on March 17, 2018.

6 "Pelecehan Seksual," available at http://www.merdeka.com/tag/p/matcontpelecehan-seksual/ accessed on March 17, 2018.

7 Nur Syam and Nawawi, "Islam Nusantara Berkemajuan sebagai Basis Moderasi Islam di Indonesia," ISLAMICA: Jurnal Studi Keislaman, Vol. 13, No. 2 (2019), 249.
} 
in morality and increase in crimes and moral violations, although the places of worship are full with those who performs rituals such as prayer congregation. ${ }^{8}$ This fact is also influenced by how each people understand religious precepts. Nurdin and Naqqiyah maintain that differences in understanding of religion can occur due to one's perspective in dealing with problems of life. Different perspectives in understanding Islamic teaching can cause different perceptions in understanding and solving various empirical matter through religious approach. A person's perception of interpreting a certain object is shaped by his social, cultural, educational, and experiential framework. ${ }^{9}$

In this regard, the fundamentals of religion are very significant in guiding Indonesian Muslim people in their social life. It is important for Muslims to understand deeply and properly the inter-relation of Islam, imān (faith), and ihsān (good deeds) that must be implemented and manifested in the daily life of Muslim as emphasized by early generations of Islam to the following centuries. As argued by Ibn Taymiyah, the implementation of Islamic teaching is based on right belief and iman and culminate to practicing good behavior and deeds iḥsān. Ibn Taymiyah's opinion refers to the explanation of the Prophet's Hadith which describes the meaning of Islam, imàn, and ihsān. ${ }^{10}$

These basic tenets to some degree can be related technically to figh (Islamic law), kalam (Islamic theology) and tasawnuf (Islamic mysticism). This view can be explained with the following example: "A person gets an order from God to pray. The ways of praying are determined in the Hadith, then discussed and systematized by the fuqaba $\vec{a}$ (fiqh experts) about the pillars of prayer, its legal requirements and laws which are taken and understood from the Qur'ān and the Hadìths which discuss a lot about prayer and those related to prayer. Besides that, he also received an order that the prayer was done in a special and unreasonable way, which was an act of the heart. Therefore, Sufism provides content to figh and on the other hand, figh provides a framework of birth control

\footnotetext{
8 Simuh, Tasawnf dan Krisis, 82-83.

9 Ali Nurdin and Maulidatus Syahrotin Naqqiyah, "Model Moderasi Beragama Berbasis Pesantren Salaf," ISLAMICA: Ju rnal Studi Keislaman, Vol. 14, No. 1 (2019), 86.

${ }^{10}$ Ibn Taymīyah, al-İmān (Cairo: al-Ṭiba'at al-Muhammadīyah, n.d.), 11.
} 
so that Sufism runs on its designated tracks." It is clear that the first and second levels are still within the scope of figh, but the next level is Sufism. Al-Ghazâli emphasized reaching the fourth level, after going through the first, second and third levels. In short, between fiqh, kalam, and tasawnuf are like buildings and the contents and decorations of these buildings. Figh is positioned as a magnificent building, kalam is the foundation of the building, and tasamwuf becomes its content and beautiful decoration.

Religious feeling and awareness do not rely only on religious formalities without substance, and not just the fulfillment of religious calls used to express one's own interests. On the contrary, religious awareness should be built upon harmony between the service of God and living in society. In other words, it is not proper for figh and kalam to be separated from Sufism, although it is not easy to enrich the integration of fiqh, kalam with sufism. In a research conducted by Somantri on TQN Suryalaya, it is maintained that this Sufi order has unique concepts, patterns, and methods that teaches religious moderation for character perfection. ${ }^{11}$ Moderation refers to individual and collective behavioral characteristics that are considered moderate, balanced, not excessive, or extreme, ${ }^{12}$ attributes that become an integral part of the social life of Indonesian Muslims. Yusuf describes and tracks the concept of religious moderation in the perspective of the Islamic trilogy ('aqidah, shari'ah, and sufism) using literature studies. The results of the study corroborate that Islam is a moderate (wasatiyah) religion, which contains three dimensions: first, the dimension of religion: (a) the godliness between atheism and polytheism, (b) the realm between reality and delusion, (c) the nature of God between ta'til and tashbih, (d) Prophethood between cult and ketus, (e) the source of truth between reason and revelation, (f) Man between al-jabr and al-ikhtiyar. Second, the dimension of shari'ah: (a) godliness and humanity (b) ideality and

\footnotetext{
11 Sokhi Huda, Tasawnf Kultural: Fenomena Shalawat Wabidiyah (Yogyakarta: LKiS, 2008), 29; Muhamad Dani Somantri and Dahwadin, "The Message of Religious Moderation in Tanbih Qadariyah Naqsyabandiyah (TQN) Pondok Pesantren Suryalaya," Theosophia: Indonesian Journal of Islamic Mysticism, Vol. 8, No. 1 (2019), 54.

12 Muhamadul Bakir Yaakub, “A Textual Analysis for the Term 'Wasatiyyah' (Islamic Moderation) in Selected Quranic Verses and Prophetic Tradirion," Journal of Education and Social Sciences, Vol. 5 (October 2016), 67.
} 
reality (c) taḅlil and tahrim, (d) individual and collective benefit, (e) assertiveness and flexibility. Third, the dimensions of Sufism: shari'ah and fact, (b) khawy and rajä', (c) physical and ruhaniyah, (d) zāahir and bätin. ${ }^{13}$

Islamic moderation does not mean that the neutral position is gray, nor is it identified with the Western paradigm that tends to fight for even open freedom. Islamic moderation is a universal value such as justice, equality, mercy, and balance that have strong historical roots in the traditions of the Prophet and companions. Such Islamic moderation can be found in every discipline of Islamic sciences, starting from the perspective of Islamic theology, Islamic thought and moderate Sufism. ${ }^{14}$ With regard to Sufism, it can be used as means of developing moderate understanding of Islamic teachings and creating moderate attitude in social dan religious life. Sauqi Futaqi states that sufistic reasoning develops an awareness to put God at the center, and gives rise to sincerity and specificity. It will also improve moral and ethical nobility, as well as inclusive and tolerant religious understanding, which eventually contribute to peace building. ${ }^{15}$ Moreover, the Sufi order, like the TQN, provides guidance for life through consistently practicing dbikr (remembrance of God) and at the same time involving in daily social life. ${ }^{16}$ As a socio-religious institution, the TQN of Suryalaya has contributed to improve the morality of its followers through building synergy between social programs and ritual practices to achieve the status of perfect human and the best community (khayr ummah). ${ }^{17}$

13 Achmad Yusuf, "Moderasi Islam dalam Dimensi Trilogi Islam (Akidah, Syariah, dan Tasawwuf)," Jurnal Al-Murabbi, Vol. 3, No. 2 (2018), 192.

14 Muhammad 'Ainul Yaqin, "Dzikir Manāqib: Moderasi Islam di Tengah Masyarakat Multikultural," Proceedings Anual Conference for Muslim Scholars, Grand Mirama Surabaya: UIN Sunan Ampel Surabaya, Vol. 2, No. 2, (2018), 929.

15 Sauqi Futaqi, "Nalar Sufistik Islam Nusantara dalam Membangun Perdamaian," DAR EL-ILMI : Jurnal Studi Keagamaan, Pendidikan dan Humaniora, Vol. 5, No. 2 (2018), 2.

16 Soleha, "Makna Hidup Bagi Pengikut Ajaran Tarekat Qadiriyah Wa Naqsyabandiyah (TQN) di Sukamara Kalimantan Tengah," Jurnal Theologia, Vol. 26, No. 2 (2015), 34.

17 Firdaus, "Tarekat Qadiriyah Wa Naqsabandiyah: Implikasinya Terhadap Kesalihan Sosial," Jurnal Al-Adyan, Vol. 12, No. 2 (2017), 37. 
The present article aims to explore and at the same time find a model of religious awareness in social life which has long been practiced by the members of TQN Suryalaya. As is known, the teachings of TQN are positioned as a framework in the assessment of educational activities. Sufi education is important and needed by all segments of society, because Sufism become one of the models for character education that integrates between individual and collective moral affairs which manifest in the form of good attitudes: honesty, responsibility, courage, manners, humility, generosity, and other values of perfect human/man (insän kämil). ${ }^{18}$ The followers of tarekat not only try to draw closer to God but also seek to unite the soul in purity, tarkiyat al-nafs (soul purifycation).$^{19}$

\section{Religious Understanding and Awareness among Members of TQN Suryalaya}

The level of understanding and awareness of the TQN community varies, depending upon the status and hierarchical position in the tarekat. There are various levels, consist of: first, murshid; second, deputy talqin; third, preachers (där); and fourth, brothers. The orderly hierarchy also indicates shows the level and quality of understanding and awareness of the TQN Suryalaya community, particularly towards the practice of Islamic teachings in the field of figh, kalam and tasammuf.

The quality of murshid's understanding and awareness of the practice of figh, kalam and tasawmuf teaching is believed to be higher than that of talqin representatives. The latter is seen as having a higher understanding and awareness than preachers; the understanding and awareness of preachers are higher than ikbwan; and the understanding and awareness of ikhwan on the practice of fiqh, kalam, and tasawnuf teaching is very diverse. The level of understanding and awareness of the TQN Suryalaya community

\footnotetext{
18 Ach. Sayyi, "Wasiat Pendidikan Sufistik Dalam Naskah Tanbih Mursyid Tarekat Qadiriyah Naqsyabandiyah Suryalaya (Telaah Pemikiran Guru Mursyid TQN Suryalaya," Jurnal Fortuna Kopertais Wilayah IV, Vol. 5, No. 1 (2017), 17.

${ }^{19}$ Marhaban, "The Implecation of Abah Anom's Dzikir on Religion in Modern Life," IOSR Journals of Humanities and Social Science (IOSR-JHSS), Vol. 22, No. 3 (2017): 45 .
} 
towards Islamic teachings embodied in fiqh, kaläm, and tasawnuf can be described as follows:

In general, there are three categories with regard to religious understanding. First, mujtabid, someone who has the ability to explore or extract laws from the argument. A mujtahid is a person who is able to create laws based on the arguments justified by shari'ah; second, muttabi', someone who accepts the opinion of another, and knows very well where that person takes the basis of his argument; and third, muqallid, someone who takes the opinion or argument of another person, but does not know exactly where that person takes his opinion. The terms mujtabid, muttabi, and muqallid are three terms commonly used among Islamic jurists.

In the contexts of Sufism, there are also three categories, namely: mubsin, muqtasid, and muslim. Mubsin is someone who gets involved in the truth that makes him not only free from wrongdoing and willing to do good, but also precedes (säbiq) in various virtues. It also means that people who do good first are those whose goodness is very much and rarely make mistakes. Muqtasid or mu'min are those who are free from wrongdoing, but their virtue is still mediocre. They are people whose goodness is proportional or at average. Muslim are those who receive the inheritance of the scriptures, believing in and adhering to its teachings, but still committing small mistakes. They are classified as people newly converting to Islam, become a Muslim, a lower level of involvement in the truth.

\section{Murshid's Level of Understanding and Awareness}

Murshid is the person appointed by the previous murshid to foster brothers who are learning to get closer to Allah with the science of scientific deeds. ${ }^{20}$ Murshid in the tarekat community in general and TQN Suryalaya in particular occupies a very high position. Everything that ikhwan does is based on his instructions and orders, as conveyed by Asep Samsurijal Hudaya, the talqin representative of Cianjur, "in the tarekat the reference is kbidmah, whatever is ordered to be done and what is prohibited to be avoided." 21 Murshid becomes the central figure in the ritual practice

\footnotetext{
20 Zaenal Abidin Anwar, Tuntunan Mujabid Dakwah (Tasikmalaya: LDTQN Pondok Pesantren Suryalaya, 2015), 55.

${ }^{21}$ Interview with Samsurijal Hudaya, Suryalaya-Tasikmalaya, May 15, 2018.
} 
of the tarekat, even his presence in the tarekat is considered a necessity, as conveyed by Asep Salahudin. According to him, "Whoever does not have a teacher in the tarekat, then the devil is the teacher." 22 Similarly, Arif Ikhwani, a talqin represent-tative from Bandung, said the same thing about the importance of murshid in the tarekat even in one's life Orphans are not those whose fathers have died, but orphans are people who do not have murshid or spiritual teachers. ${ }^{23}$

In the TQN Suryalaya, murshid is important figure and his position is very central and charismatic. His sayings have been documented as books, such as the Principles and Objectives of the TQN, Worship as a Method of Guidance for Victims of Narcotics Abuse and Juvenile Delinquency, Miftāh al-Șuìr, 'Uqüd al-Jumān (guidelines for dhiker practice for the community of TQN Suryalaya), Tanbih (wills from the leadership of TQN Suryalaya for the entire tarekat community that must be implemented), tawassul (recommended regular readings to the TQN Suryalaya community), Manáqib (practice that is conducted regularly every month on the eleventh day of the hijri month), Akblak Karimah (a reference book that regulates the good behavior of other), and their behavior is considered a "truth" and become role models for all brothers, including talqin representatives and the preacher. All students (ikbwan) are not allowed to practice the teachings of TQN Suryalaya without the guidance and supervision of the murshid, let alone make their own teachings on behalf of TQN Suryalaya. Normatively, people who have the authority to guide and determine which teachings riyädah must be practiced by students are only the murshid, or people who are trusted by him, such as representatives of talqin. Other people cannot guide, let alone make new teachings, without the permission of the murshid or talqin representatives.

The teachings of kalam and tasammuf are conveyed by the murshid to his students (ikhwan), when the process of talqin (early stages to become a community of TQN Suryalaya by providing advice related to dhikr), dhikr (a series of special readings recommended for the TQN Suryalaya community), khataman (special practices

\footnotetext{
22 Asep Salahudin, "Ringkasan Disertasi" (Bandung: Pascasarjana Universitas Padjadjaran, 2012), 55.

${ }^{23}$ Interview with Arif Ikhwani, Suryalaya-Tasikmalaya, October 6, 2018.
} 
that are carried out regularly every Monday and Thursday), and manakiban (practice that is conducted regularly every month on the eleventh day of the bijri month). Each ikhwan is required to have wudu', according to provisions that apply among fiqh experts. The murshid of TQN Suryalaya really understands and realizes that every practice of the tarekat is a teaching that emanates from it as combination of three important dimensions: fiqh, kalam and tasamwn. The level of understanding and awareness of the murshid regard to fiqh, kalam and tasawnuf can be included into the category of mujtahid, dhiker, khataman, and manakiban.

\section{Talqin Representative's Level of Understanding and Awareness}

Talqin representatives in the TQN Suryalaya community are important agents in the development of this tarekat. Through their role, the followers (ikhwain) of this tarekat are widespread in various regions, not only in Indonesia which stretch from Sabang to Merauke, but also overseas, such as in Malaysia, Brunei Darussalam, Singapore and other countries. The position of ikhwann before the murshid is the same and equal.

The difference between talqin representatives and ikhwan is that the former is trusted and given authority by murshid to convert those who want to learn the TQN teachings. Due to various factors, such as psychological and geographical (distance from Suryalaya as the center), it is difficult for the followers to receive talqin directly from the murshid. Therefore, the talqin representatives have the responsibility to foster, develop and expand ikbwàn networks. The appointment of an ordinary ikhwan to be the talqin representative in the TQN Suryalaya exclusively becomes prerogative of the murshid, and therefore no one, even the family (abl al-bayt) knows. ${ }^{24}$

Salahudin states that talqin representatives have four types: First, intellectual/modernist academics, namely talqin representatives who master the tradition of classical Islamic sciences/knowledge, combined with modern scholarship. According to him, this type often conveys the message of tarekat and Sufism in modern terms, so it can be understood rationally and logically. Sufism gets its clear ontological, epistemological, and axiological basis. Tarekat is examined not only as part of past literacy but also related to the

${ }^{24}$ Interview with Asep Salahudin, Suryalaya-Tasikmalaya, June 29, 2018. 
context of recent scientific developments, such as how the tarekat is linked to the political, social, cultural, and philosophical domains. In communicating the messages of tarekat, it is not only from the normative side but also practical empirical aspect of the tarekat teachings which are relevant to all levels of society and the cultural dynamics. Talqin representatives who belong to this type include among others Juhaya S. Praja, Ahmad Tafsir, both are Professors at Universitas Islam Negeri (UIN) Sunan Gunung Djati Bandung, and Ustadh Ali from Singapore. These talqin representatives rarely convert to the masses, and in delivering the teaching of the tarekat they are supported by academic studies. This first type of representatives is especially relevant for the upper middle class, the campus and the academic community. Their da'wah is often formulated in scientific language, so the media used are academic books.

Second, traditionalist ulama, talqin representatives who have the ability to master kitab kuning (the classical Islamic books), before they are appointed. Talqin representatives who belong to this type are, among toehrs, Zezen Bajul Ashab (leader of the Pesantren Azzainiyah Sukabumi as well as Chairman of Indonesian Ulama Council and Sukabumi Indonesian Mosque Council), Ajengan Beben (Pamijahan), and Zainal Abidin Anwar (leader of Pesantren Suryalaya). In conveying the tarekat teachings, this type of talqin representative combines tarekat with the background of the Islamic tradition that they previously studied. They are often invited to lecture at manakiban events because they are very communicative and "popular" so they are welcome in every manakiban and have a place in the hearts of ikhwan. Some of them are diligent in writing, even though the writing does not follow academic standards or requirements, like using footnotes. However, because the language is easy to digest and contains materials that encourage a person to become a true Sufi, the book is very popular among the middle to lower ikhwans. Anwar's book, Inabab: Healing Drug Victims is one of the examples.

Third, neo-traditionalist scholar, talqin representative who had previously attended pesantren and at the same time took academic degrees in higher education. These talqin representatives include Otong Sidiq Djajawisastra (graduated from Universitas Padjadjaran [UNPAD] in Sundanese Literature), Arief Ikhwani (graduated 
from UIN Bandung), Wahfiudin (a trainer), and Sandisi (graduated from Institut Agama Islam Latifah Mubarokiyah [IAILM] Suryalaya, Tasikmalaya). In preaching the tarekat, this type of representative is easy to understand, because they can deliver the teachings in modern terms. This type of talqin representative can be distinguished from the first type, where this third type does not have a complete understanding of the primary sources of the tarekat and does not document their thoughts in scientific works, even though they have studied in universities.

Fourth, traditional conservative, talqin representatives outside the three categories above and come from diverse sociointellectual backgrounds. ${ }^{25}$ These talqin representatives come from soldiers, 'thugs', business people, and civil servants. They feel that there has been a surge in spiritual experience after being mentored by murshids, such as Ustadh Ali Hanafiah, an influential talqin representative and kiai in East Java, whose recitation is attended by thousands of people.

The four types of talqin representatives who become the main mouthpieces after murshid in TQN have advantages and disadvantages, and therefor this situation enable them to complement each other. This diversity of levels may be intended as the murshid's strategy in developing the tarekat from one region to another, so TQN has become the largest tarekat in Indonesia.

\section{Muballigh's Level of Understanding and Awareness}

The talqin representative as well as one of the three people who carry out the mandate of Pesantren Suryalaya is called muballigh who is trained to convey God's revelation. ${ }^{26}$ According to Anwar, "what we convey must have a clear source, and so preachers should not just talk." In addition, a preacher must have a standard or basic knowledge of what he will convey. There are three standards or conditions: knowing and practicing religious materials/teaching they convey; knowing exactly whom to meet when delivering religious materials, and paying attention to the situation of mustami (listeners/audiences); having skills, special competencies, techniques, and methods of delivering the materials.

\footnotetext{
${ }^{25}$ Salahudin, "Ringkasan Disertasi," 60-62.

${ }^{26}$ Interview with Zaenal Abidin Anwar, Suryalaya-Tasikmalaya, April 30, 2018.
} 
Muballigh in the TQN Suryalaya are those who have the ability to convey the messages of the tarekat to community, especially ikhwan, either in the context of guidance, or other information related to social, political, cultural or economic matters. In order to help ease the burdens of the murshid in conveying the tarekat messages to a wider area, muballigh plays important roles. ${ }^{27}$ According to Salahudin, the strategic function of preachers (muballigh) is as murshid assistants in fostering Ikbwan of TQN Suryalaya community. The preachers are expected to be the driving force of the brothers or sisters and even all the Muslims around them in implementing the tarekat rituals at the Pesantren Suryalaya, in addition to maintaining good, to be honest, polite and courteous in speech and behavior so as to generate sympathy, especially making the preachers role models for the community. ${ }^{28}$

Salahudin maintains that there are at least four types of preachers in the TQN. The four types are as follows: First, pesantren preachers, those who focus their tabligh (preaching) in the pesantren in order to prepare credible human resources, especially the relatives through education. Second, campus preachers, those who preach on campuses, both public and private. Third, political preachers, those who are actively involved in the practical politics and their political affiliations mostly follow their murshid, namely Golongan Kary; and Fourth, stage preachers, those who at any time deliver lectures in various places.

Then, if one examines the level of understanding and awareness of the TQN Suryalaya preachers regarding the practice of fiqh, kalam, and tasammuf in the tarekat, it is revealed that their level is not much different from that of the talqin representatives. Both have the same obedience to the murshid. What the murshid ordered is what they have to do, and what the murshid forbade is what they should leave. In front of the murshid, they position themselves like a deceased (mayyit). What they deserve depends entirely on the guidance of the murshid. Therefore, it is not an exaggeration to say that their behavior is almost like the behavior of the murshid. They really try to imitate murshid to the maximum degree, even though in their minds (talqin representatives and muballighs) there is a strong belief that it is very unlikely that what they have been doing so far

\footnotetext{
27 Salahudin, "Ringkasan Disertasi," 62.

${ }^{28}$ Salahudin, 63.
} 
will be exactly the same as murshid, both in terms of how they should practice the teachings of TQN Suryalaya, such as dhiker, khataman, manakiban, riyädah, and others, and how the murshid interacts with the public, as to deal with, entertain or treat guests who come to Suryalaya from various backgrounds, to teach the tarekat to ikhwan, and to build a tarekat network. They certainly do not miss the way murshid understands and realizes integrally the practices of figh, kalam, and tasammuf. The four types of TQN Suryalaya preachers are seen to understand and realize that every practice including the practice of the tarekat, especially those taught in TQN Suryalaya, contains dimensions of fiqh, kalam, and tasawwuf integrally. The level of understanding and awareness of the TQN Suryalaya community preachers in the practice of figh, kalam, and tasammuf are included in the category of muttabi (followers).

\section{The Level of Understanding and Awareness of Ikhwān}

Ikbwan is the name for the TQN Suryalaya community. They come from various groups of people with different social status and professions. In addition, ikhwān form a group of tarekat practitioners who do not have additional duties such as talqin representatives and missionaries. Someone is said to be an ikhwain if he has received talqin from the murshid or from someone who has a mandate from him the murshid, namely the talqin representative.

In general, there are two motivations of an ikhwan to learn the tarekat, namely li al-suluk (for practicing) and li al-tabarruk (for the sake of blessing). According to Ajid Thohir, ikbwan li al-suluk is a group of brothers who not only practice the rituals of tarekat, but also study its teachings deeply, and have the potential to convey their experiences of practicing the tarekat to others. ${ }^{29}$ Meanwhile, ikhwan li tabarruk are those who concentrate more on the practice of their tarekat rather than studying them in detail. For this group, knowledge about the tarekat teaching is not so important, as they emphasize on practicing the rituals of tarekat as have been exemplified by murshid or talqin representatives, as asserted by Ahdi Nuruddin, an ikhwān and murshid teacher. ${ }^{30}$

\footnotetext{
${ }^{29}$ Interview with Ajid Thahir, Suryalaya-Tasikmalaya, June 6, 2018.

${ }^{30}$ Interview with Ahdi Nuruddin, Suryalaya-Tasikmalaya, June 6, 2018.
} 
Salahudin classifies ikhwàn into two types: first, pragmatic, those who come to Suryalaya with pragmatic goals, such as wanting to move up the ranks or positions, or hoping to prosper, and their business develop, even wanting to become civil servants, etc. and second, ideological, which is divided into two types: academic and populist. The academic ideological type of ikhwan can be characterized as follows: (1) although they are part of the tarekat, they still think critically, not all of the tarekat's reasoning is taken for granted; (2) they are more engaged in scientific studies (seeking scientific bases and developing epistemology related to Sufism and tarekat), but often neglect aspects of its rituals ('amaliyah) and experience); (3) they do not have a strong bond to follow all the rites of the tarekat. The populist ideological type occupies the lowest layers in the tarekat community. This type is characterized by: (1) dogmatic, that is, all the teachings of the tarekat are accepted without having to consider the rational side, the belief is more important than reasoning; (2) stronger side of 'amaliyah (practicing the teachings of tarekat) rather than knowledge for this group what is being developed is an understanding that tarekat is not science or knowledge, but rituals or practices. If knowledge is obtained, it will be generated through rituals. ${ }^{31}$

The majority of $i k h w a n$, especially the populist type in practicing the teachings of tarekat do not consider emphasize the rational side, but more on faith. As a result, the side of 'amaliyah is stronger, and this comes out of a sense of mahabbah (love) and solemnity towards murshids. It is on this basis, in my observation, that most of ikhwàn, both pragmatic and ideological, tend to "join in" (Sundanese: gehgeran) the tarekat. Whatever the practice of the tarekat they receive from murshids, talqin representatives, preachers or fellow brothers, as long as these practices according to them are really the teachings of TQN, they practice them.

Such attitude of ikbwan of course will affect all forms of practice including the level of their understanding and awareness toward fiqh, kalam, and tasawnuf. They will not care whether the practice of worship, including the practice of the tarekat they have been doing, is contained in the dimensions of fiqh, kalam, and or tasawnuf. In their minds, there is an "omnipotent" belief that if

31 Ibid. 
they carry out the teachings of the tarekat, especially TQN Suryalaya in earnest, whose methods, procedures and ceremonies are in accordance with the instructions of murshid or talqin representatives as written in the TQN Suryalaya guidebooks written directly by the murshid, then it is certain that the practice contains extraordinary blessings. As stated by Faisal, an ikhwān who is also the Secretary of the Fakulty of Syariah of IAILM Suryalaya: "urang mah ka Suryalaya teh dina raraga ngalap baraka" (I went to Suryalaya in order to seek blessings). According to him, no matter how small the practice of the tarekat that is carried out, it is intended certainly to get blessings. ${ }^{32}$ Ayi Rohim asserts the same, that the more important is to get blessing rather than salary or money from the IAILM Suryalaya. ${ }^{33}$ Thus, the level of understanding and awareness of most of ikhwan of the TQN Suryalaya community, different from talqin representatives and preachers can be included in into the category of muqallid. Based on the explanation above, the level of understanding and awareness of ikhwain towards the practice of figh, kalam, and tasawnuf can be classified as follows:

\begin{tabular}{|c|c|c|c|c|c|c|}
\hline Quality & \multicolumn{3}{|c|}{ Fiqh Expert Category } & \multicolumn{3}{|c|}{ Sufism Expert Category } \\
\hline Quantity & Mujtabid & Muttabi ${ }^{`}$ & Muqallid & Muḅsin & Muqtașid & Muslim \\
\hline Murshid & $\checkmark$ & & & $\checkmark$ & & \\
\hline $\begin{array}{l}\text { Deputy } \\
\text { Talqin }\end{array}$ & & $\checkmark$ & & & $\checkmark$ & \\
\hline Missionary & & $\checkmark$ & & & $\checkmark$ & \\
\hline $\begin{array}{l}\text { Brother- } \\
\text { hood }\end{array}$ & & $\checkmark$ & $\checkmark$ & & $\checkmark$ & $\checkmark$ \\
\hline
\end{tabular}

\section{Sources of TQN Religious Practice in Social Life}

As has been stated, the teachings of TQN Suryalaya contain three important dimensions, namely fiqh, kalam, and tasawwuf. This can be seen clearly in the materials used as references for teachings that must be implemented in daily practice. These three dimensions always animate every teaching practiced by ikhwān,

\footnotetext{
32 Interview with Faisal, Suryalaya-Tasikmalaya, June 27, 2018.

${ }^{33}$ Interview with Ayi Rohim, Suryalaya-Tasikmalaya, June 26, 2018.
} 
especially at the core of its teachings: namely dhikr as daily practice, khataman as weekly practice and manakiban as monthly practice. These three dimensions also characterize tanbih as a guide for ikhwan of the TQN, where every ikhwan is obliged to adhere to the tanbih in living his life, especially in religion, society, nation and state. In addition, these three dimensions are clearly visible in TQN Suryalaya's vision, namely "Science of Scientific Rituals." Abah Anom advised all the brothers and sisters of the TQN Suryalaya order to always base their practice on knowledge, and whatever they do must be in accordance with scientific provisions. This vision suggests that Abah Anom as TQN Suryalaya murshid does not want his students to practice rituals without having knowledge about it. Abah Anom advices his followers to be willing to seek knowledge, because he does not want his students to follow without knowledge (taqlid) of the teaching of tarekat, and all of worships and rituals. However, in reality, there are many ikhwans who may be categorized into the type of muqallid. ${ }^{34}$

In addition, fiqh, kalam, and tasammuf can also be seen in their colors in the social life of the TQN Suryalaya community. For an example is how they treat guests who come to Pesantren Suryalaya. The tradition is that every guest who comes to the pesantren whether those who intend to study the tarekat, make a pilgrimage (ziyarah) to the murshid's grave or only want to do research, they are usually welcome and treated with food or meal. As said by Nana Suryana, anyone who comes to Suryalaya must be given eat however much. ${ }^{35}$ Of course, it is just a small example from many of how the tarekat and pesantren treat guests from different backgrounds and status. This also reflects the practice of the tarekat teachings in respecting people, and exhibit the intersection between understanding and awareness of the practice of figh, kalam, and tasammuf in daily practice.

In fact, the practice of fiqh, kalam, and tasawmuf in the TQN Suryalaya community is normatively depicted in six main teachings: First, Talqin. It has a central position in TQN Suryalaya. It is believed to be the entrance for a person to become part of the TQN Suryalaya community. Because of the importance of this

\footnotetext{
34 Ahmad Shahibulwafa Tadjul Arifin, Akblaqul Karimah Akblaqul Mabmudah (Tasikmalaya: Yayasan Serba Bhakti Pondok Pesantren Suylaya, 1983), 15.

${ }^{35}$ Interview with Nana Suryana, Suryalaya-Tasikmalaya, June 29, 2018.
} 
talqin, only murshids and talqin representatives have the authority to convert someone who requests it not on the basis of coercion. Second, Miftäh al-Sudür. This book is an important work of Abah Anom as a guide for brothers (ikhwan) so that they can practice the TQN Suryalaya based on the instructions of the murshid described in the book.

The book is present in the midst of the TQN Suryalaya community and is intended to strengthen the teachings of the murshid that rituals must be based on absolute knowledge and knowledge is proven in the form of rituals/actions, as clearly engraved in Suryalaya's motto, "the science of scientific rituals." According to Ahmad Shohibulwafa Tadjul Arifin, there are two kinds of knowledge: outer/physical (zăhir) knowledge and inner (bätin) knowledge, as the following expression:

There are two kinds of knowledge, namely physical knowledge and inner knowledge. Physical knowledge is regulated by fiqh so that we can open up spiritual worship. Science is born also to explain other people's questions about laws and regulations such as how ablution, prayer, fasting, these are all governed by the science of figh. The two sciences that fill the heart that bring benefits are regulated by the science of Sufism. Both of these sciences must be studied by us so that they are physically, physically and mentally directed. Do not be lame, there is no inside, there is no outside. Everything will not work if only the outer tire without the inner tube, so it is with knowledge that must be born and inside. ${ }^{36}$

Abah Anom's statement emphasized that all TQN Suryalaya brothers are required to study and understand the Miftāh al-Sudūr first before practicing the teachings of TQN. This is important for ikhwan, because the book is a basic guideline that explains the importance of $d h i k r$, starting from the nature of $d b i k r$, the way of doing dhikr, the principles of talqin in dhikr, to how dhikr affects spiritual education. It is difficult for someone to practice dhikr while he is not good at dhikr. Therefore, before stepping into the next stage of the tarekat rituals, someone must master the Miftăh al-Sudūr.

${ }^{36}$ Arifin, Akblaqul Karimah, 80. 
Third, 'Uqūd al-Jumān, containing a guide for the daily practice of TQN Suryalaya. It is hoped that after someone is converted, and strengthened by the knowledge contained in the Miftäb alSudür, he must practice the contents of the 'Uqüd al-Jumann as a whole (should not be reduced, added, changed or replaced in terms of theory or practice) consistently in accordance with the murshid's provisions. In addition to the practices contained in 'Uqüd al-Jumān, ikhwàn are also encouraged to carry out incidental rituals ('amalīyah) including rìä dah, pilgrimage, ngaras, rejecting balä' and so on. In order to measure the success (whether or not it is true in practicing the content of 'Uqüd al-Jumān, Abah Anom has provided guidelines, that is the akblakul karimah as a standard of success. ${ }^{37}$

Fourth, Akblakul Karimah Akblakul Mahampang, a book based on mudäwamat dhikr Alläh. This book shows the peak achievement of the spiritual practices of ikhwan, namely a man who is able to control his passions, as conveyed by Sufi scholars:

It is truly noble for a human to always control his passions; because as a human being is truly thought, has strong faith, resilient in facing his enemy who becomes a disease in his heart. As for humans who are filled with mental diseases (heart), namely the seduction of demonic lust, such as takabbur, jealousy, evil, revenge, greed, slander and so on, resulting in dirty deeds (which can cause disaster to the family and society), thus culminating into a heinous deed (it can wreak havoc on society and the country), even riots to all mankind, they died classified as unbelievers. ${ }^{38}$

It can be interpreted that heart disease is Satan's temptation and the seduction of lust, if people follow it then there will be bad qualities (madhmumah), such as takabbur, jealousy, and the hedonics. ${ }^{39}$ The main function of prophethood is to build an order of life that is oriented towards morals, as the Prophet Muhammad said: "In fact I was sent to perfect morality." Even as it has been stated in the Qur'ān, Muhammad's glory lies on the greatness of his morals, as al-Qalām [68]: 4 reads: "And in fact you are truly noble in character."

\footnotetext{
${ }^{37}$ Anwar, Tuntunan Mujabid Dakwah, 56.

38 Arifin, Akblaqul Karimah, 1-2.

${ }^{39}$ Ibid., 2.
} 
Fifth, Book of Worship as a Method for Coaching Victims of Narcotics Abuse and Jwvenile Delinquency. This book symbolizes the stages of brothers who have been consistent (istiqamah in practicing the teachings of TQN Suryalaya. Worship fulfills not only the physical aspects of figh, but also the inner dimensions of Sufism, both vertical and horizontal; and Sixth, Tanbih, a manifesto of the teachings of TQN Suryalaya. According to its name, "reminding," this guides all ikhwān how to behave towards religion, the state and society. For this reason, Tanbih is always recited not only in official TQN Suryalaya rituals, such as manakiban, but also at various social events. Tanbih is a link that connects the awareness of the brothers in practicing the teachings of TQN Suryalaya in its totality.

These six main teachings can be used as a reference and guidance in implementing, securing and preserving the practice of TQN Suryalaya and the mandate of the Murshid Guru (murshidteacher) as good as possible at all times. Anwar states: "It is an obligation for all of us as students to consistently follow the teacher: 'Oh my Lord, you are what I mean and I am looking for Your pleasure, so give me the ability to act and be blessed with You." $" 40$

According to Anwar, the description of the success of a student who practices the teachings of TQN Suryalaya has been clearly written by Pangersa Abah Sepuh (Shaykh KH. Abdullah Mubarok b. Nur Muhammad) in Tanbih which is always recited in every manakiban and other activities. As stated in Tanbih, every ikhwan must prove the virtue that arises from holiness: ${ }^{41}$ First, we have to respect people who are higher than us, both zähir and bätin, that is how we should live in harmony and respect each other.

Second, for others who are equal to us in everything, do not cause disputes, on the contrary we must be humble, cooperate in carrying out religious and state orders, do not cause disputes and disputes, in case we are exposed to His word "adhäb alim," which means grief forever from the world to the hereafter (the body is hard-hearted).

Third, Towards people whose condition is below us, do not want to insult him or act indecently, be arrogant, on the contrary it must be compassionate with awareness, so that they feel happy

\footnotetext{
40 Anwar, Tuntunan Mujabid Dakwah, 57.

${ }^{41}$ Anwar, 58.
} 
and excited in heart, do not feel afraid and wild, as if their heart was cut, on the contrary they must be guided by gentle advice that will give conviction in treading the path of goodness.

Fourth, towards the poor must be affectionate, warm and kind, be generous, reflecting that our hearts are aware. Try to feel ourselves personally, how painful it is to be in a state of deprivation, therefore do not be indifferent, only yourself are happy, because they are poor, it is not their own will, but that is God's nature.

According to Anwar, all these represent a picture of the morality of a brother who really practic es the teachings of TQN Suryalaya and understands the very great strands of pearls: "stop working if hurt, and love people who hate us." Thus, said Abah Sepuh, as quoted by Anwar:

All students should act carefully in all the paths they take, for the good of the heart, the world and the hereafter, so that the heart is at ease, the body is comfortable, do not disagree at all, no another goal is the main mind of the perfect body. There is no other practice that we do in TQN Suryalaya, do our best to achieve all the good, stay away from all evil gähir-bätin which is connected with body and spirit, which is always shrouded in the seduction of lust, seduced by the devil's power.

Based on this explanation, the relationship between understanding and awareness of ikhwam of TQN Suryalaya in relation to the integration of awareness of diverse religious experiences is al-tadarruj (tiered and sequential unity).

\section{Conclusion}

The integration of religious awareness in social life in the TQN Suryalaya community is very diverse. In terms of quantity and hierarchy, the community is divided into several levels: murshid; talqin representatives (academic/modernist, ulama-traditionalist, scholar-neo-traditionalist, and traditional conservative); preachers (pesantren, campus, politics, and stage); and ikhwän (pragmatic and ideological). Meanwhile, in terms of quality, the community is divided into three categories: mujtabid; muttabi, and muqallid. These three terms are equivalent to the terms in Sufism: muhsin, muqtașid, and muslims. The main sources as references of the tarekat consist of Talqin, Miftḥ al-Sudūr, Uqüd al-Jumān, Akblakul 
Karimah Akblakul Mahmudah, Book of Worship as a Method of Fostering Victims of Narcotic Abuse and Juvenile Delinquency, and Tanbih. Substantively, the form of the relationship between understanding of the TQN Suryalaya community and the practice of religious teachings in social life is reflected as "a tiered and sequential unity."

\section{Bibliography}

\section{Books and Articles:}

"Berita-Berita-Kriminalitas-Terbaru," available at http://beritaterpopuler.com/berita/berita-kriminalitasterbaru.html. accessed on March 17, 2018.

"Kasus-Pelanggaran-Hak-Asasi-Manusia," available http://www.yoedha.com/2012/01/kasus-pelanggaran-hakasasi-manusia.html. accessed on March 17, 2018.

"Memprihatinkan-Jumlah-Kasus-Kdrt-Meningkat," available at http:/ /jurnalberita.com/2012/05/memprihatinkan-jumlahkasus-kdrt-meningkat. accessed on March 17, 2018.

"Pelecehan Seksual," available at http://www.merdeka.com/tag/p/matcont-pelecehan-seksual/ accessed on March 17, 2018.

"Pelecehan Seksual," available at http://www.merdeka.com/tag/p/matcont-pelecehan-seksual/ accessed on March 17, 2018.

Anwar, Zaenal Abidin. Tuntunan Mujabid Dakwah. Tasikmalaya: LDTQN Pondok Pesantren Suryalaya, 2015.

Arifin, Ahmad Shahibulwafa Tadjul. Akblaqul Karimah Akblaqul Mahmudah. Tasikmalaya: Yayasan Serba Bhakti Pondok Pesantren Suylaya, 1983.

Firdaus. "Tarekat Qadiriyah Wa Naqsabandiyah: Implikasinya Terhadap Kesalihan Sosial," Jurnal Al-Adyan, Vol. 12, No. 2, 2017.

Futaqi, Sauqi. "Nalar Sufistik Islam Nusantara dalam Membangun Perdamaian," DAR EL-ILMI: Jurnal Studi Keagamaan, Pendidikan dan Humaniora, Vol. 5, No. 2, 2018.

Huda, Sokhi. Tasawnf Kultural: Fenomena Shalawat Wabidiyah (Yogyakarta: LKiS, 2008.

Ibn Taymīyah. al-İmān. Cairo: al-Ṭiba'at al-Muhammadiyah, n.d. 
Marhaban. “The Implecation of Abah Anom's Dzikir on Religion in Modern Life," IOSR Journals of Humanities and Social Science (IOSR-JHSS), Vol. 22, No. 3, 2017.

Nurdin, Ali and Maulidatus Syahrotin Naqqiyah. "Model Moderasi Beragama Berbasis Pesantren Salaf," ISLAMICA: Ju rnal Studi Keislaman, Vol. 14, No. 1, 2019.

Salahudin, Asep. "Ringkasan Disertasi." Bandung: Pascasarjana Universitas Padjadjaran, 2012.

Sayyi, Ach. "Wasiat Pendidikan Sufistik Dalam Naskah Tanbih Mursyid Tarekat Qadiriyah Naqsyabandiyah Suryalaya (Telaah

Pemikiran Guru Mursyid TQN Suryalaya," Jurnal Fortuna Kopertais Wilayah IV, Vol. 5, No. 1 (2017), 17.

Simuh. Tasawnf dan Krisis. Yogyakarta: Pustaka Pelajar, 2001.

Soleha. "Makna Hidup Bagi Pengikut Ajaran Tarekat Qadiriyah

Wa Naqsyabandiyah (TQN) di Sukamara Kalimantan

Tengah," Jurnal Theologia, Vol. 26, No. 2, 2015.

Somantri, Muhamad Dani and Dahwadin. "The Message of Religious Moderation in Tanbih Qadariyah Naqsyabandiyah (TQN) Pondok Pesantren Suryalaya," Theosophia: Indonesian Journal of Islamic Mysticism, Vol. 8, No. 1, 2019.

Syam, Nur and Nawawi. "Islam Nusantara Berkemajuan sebagai Basis Moderasi Islam di Indonesia," ISLAMICA: Jurnal Studi Keislaman, Vol. 13, No. 2, 2019.

Yaakub, Muhamadul Bakir. "A Textual Analysis for the Term 'Wasaatiyyah' (Islamic Moderation) in Selected Quranic Verses and Prophetic Tradirion," Journal of Education and Social Sciences, Vol. 5, October 2016.

Yaqin, Muhammad "Ainul. "Dzikir Manāqib: Moderasi Islam di Tengah Masyarakat Multikultural," Proceedings Anual Conference for Muslim Scholars, UIN Sunan Ampel Surabaya, Vol. 2, No. 2, 2018.

Yusuf, Achmad. "Moderasi Islam dalam Dimensi Trilogi Islam (Akidah, Syariah, dan Tasawwuf)," Jurnal Al-Murabbi, Vol. 3, No. 2, 2018.

\section{Interviews:}

Zaenal Abidin Anwar, Suryalaya-Tasikmalaya, April 30, 2018. Samsurijal Hudaya, Suryalaya-Tasikmalaya, May 15, 2018. Ahdi Nuruddin, Suryalaya-Tasikmalaya, June 6, 2018. 
Ajid Thahir, Suryalaya-Tasikmalaya, June 6, 2018.

Ayi Rohim, Suryalaya-Tasikmalaya, June 26, 2018.

Faisal, Suryalaya-Tasikmalaya, June 27, 2018.

Asep Salahudin, Suryalaya-Tasikmalaya, June 29, 2018.

Nana Suryana, Suryalaya-Tasikmalaya, June 29, 2018.

Arif Ikhwani, Suryalaya-Tasikmalaya, October 6, 2018. 